\title{
THE USES OF SOCIAL SCIENCE IN TRIALS WITH POLITICAL AND RACIAL OVERTONES: THE TRIAL OF JOAN LITTLE*
}

\author{
JOHN B. MCCONAHAY $\dagger$ \\ Courtney J. Mullint† \\ JEFFREY FREDERICK**
}

\section{INTRODUCTION}

One unintended by-product of the zealous prosecution of political and racial militants in the recent past has been the increased participation by social scientists in the judicial arena. The presence of social psychologists and sociologists was obvious in the more publicized cases, e.g., the Harrisburg Eight, ${ }^{1}$ the Camden $28,{ }^{2}$ and the Gainesville Eight. ${ }^{3}$ Applied social scientists have also worked in trials involving persons from the right wing of the political spectrum, e.g., Mitchell-Stans, ${ }^{4}$ and in an increasing number of lesser known criminal cases. Now, at least two organized groups of social scientists, the National Jury Project and the Raleigh-based Psychology and Law Center, are permanently established for consultation in both criminal and civil litigation. In this article we will draw upon our experiences in another of the better known trials, that of Ms. Joan Little, to illustrate some of the contributions of social scientists to the judicial process and to discuss some of the issues raised by the application of social science to the law.

The Joan Little case began in Washington, North Carolina. Early on the morning of August 27, 1974, Clarence Alligood, the night jailer for the Beaufort County jail, was found dead in a locked cell in the women's section of the jail. Alligood, a sixty-four-year-old white male, had ice pick punctures

\footnotetext{
* Research on this project was supported by grants to John B. McConahay from the Society for the Psychological Study of Social Issues and from the University Research Council of Duke University. Their assistance is gratefully acknowledged. The, authors wish to thank Betsey DeHaas, Virginia Nichols, Lorin Peri Palmer, and Wanda Settles for serving as interviewers and Deborah Little Dean for typing many drafts of the manuscript. We also wish to thank Professors Philip J. Cook, John Kaplan, Robert Kraut, and Bernard Segal for their comments on an earlier draft of this paper. We did not always follow their advice, but their criticisms helped to clarify our thinking.

$\dagger$ Associate Professor of Policy Sciences and Psychology, Duke University.

$\dagger \dagger$ Graduate Student, Department of Psychology, North Carolina State University

** Graduate Student. Department of Psychology. North Carolina State University

1. United States v. Ahmad, 347 F. Supp. 912 (M.D. Pa. 1972).

2. United States v. Anderson, 356 F. Supp. 1311 (D.N.J. 1973).

3. United States v, Briggs, 366 F. Supp. 1356 (M.D. Fla. 1973).

4. United States v. Mitchell, 372 F. Supp. 1239 (S.D.N.Y. 1973).
} 
in his body and semen on his leg; and his pants and shoes were outside the cell. The person incarcerated in the cell during the preceding weeks was Joan Little, a twenty-year-old black female. Both Ms. Little and the keys to the cell and jail were missing. Over the next few days, there was an extensive search for Ms. Little in Beaufort and adjacent counties. She was on the verge of being declared an outlaw ${ }^{5}$ when, accompanied by her attorney, Jerry Paul, she turned herself in to the authorities in Raleigh. She was immediately charged with first degree murder. On April 28, 1975, her trial was moved from Beaufort to Wake County (Raleigh), North Carolina. And on August 15, after a trial of five weeks, she was acquitted of all charges.

The case created an avalanche of publicity. Alligood's death, Little's disappearance, the search for her, and her surrender were covered extensively in the local, state, and national news media. And because her case touched upon three currently sensitive political issues-women's rights, racism, and prison reform-she attracted financial and moral support from a large number of politically active persons and organizations. Consequently, she was the subject of many feature articles in the print media and received a great deal of television coverage during the interim between her arrest and trial. The trial was extensively reported by newspapers and television in the United States and Europe.

The same issues that made her case of interest to political partisans and the media made it attractive to social scientists as well. Many social scientists gave freely of their research time and skills during both the pre-trial and trial phases. Although all of our activities on her behalf attracted some attention, our presence during the voir dire of prospective jurors attracted the most attention and controversy. However, our contribution to the grand jury composition challenge, and especially to the change of venue motion, was perhaps more important than the jury selection in determining the outcome of the trial.

\section{The Composition Challenge}

The United States Supreme Court has ruled that the pool of persons from which grand and petit juries are selected must represent a cross-section of the community in which the court is situated. ${ }^{6}$ Because the jury selection system

5. In 1974, North Carolina was one of the few states that still had an outlaw statute. N.C. Gen. Star. \$ 15-48 (1969). If the Beaufort County Superior Court Judge had declared Ms. Little an outlaw, then she could have been killed on sight by any citizen without benefit of trial or any other due process. This statute was declared unconstitutional in late 1976 by Autrey v. Mitchell, 420 F. Supp. 967 (E.D.N.C. 1976).

6. Alexander v. Louisiana, 405 U.S. 625 (1972); Turner v. Fouche, 396 U.S. 346 (1970); Thiel v. Southern Pacific Co., 328 U.S. 217 (1946); Smith v. Texas, 311 U.S. 128 (1940); Strauder v. West Virginia, 100 U.S. 303 (1880). A more complete discussion of the law on jury composition challenges may be found in Kairys, Juror Selection: The Law, A Mathematical Method of Analysis, and 
in a given judicial district is presumed representative, the burden of proof rests upon the litigant challenging the composition. A prima-facie case against representativeness can be made in four ways: 1) show bias in the source from which names are drawn; 2) show bias in the process used to select names; 3) show that the result of the selection process "substantially" departs from representativeness; or 4) show that the procedures for selection violated statutory standards. ${ }^{7}$ Demonstrating any one of these four conditions is sufficient to support a prima-facie case. Social scientists can assist in demonstrating any of the four, but they can be especially helpful in the first three instances.

For example, it is a well established finding of the voter participation studies that blacks, women, younger and older people, blue collar workers, the less educated, and lower income persons are seriously underrepresented among registered and actual voters relative to their numbers in the general population. ${ }^{8}$ Hence, social scientists expert in this field of research can testify that in most jurisdictions any selection process that uses only voter registration lists or only actual voters will have to start with a biased source. At least one lower court has ruled that using voter lists as the only source is unconstitutional. ${ }^{9}$ However, although it is a well established canon of statistics that starting with a biased source makes it impossible to produce a representative result no matter what cosmetics might be applied to make the final results appear to be so, the thrust of most court decisions has been to allow voting lists as a source unless it can be shown that the underrepresented "cognizable classes" " have been deliberately discouraged or barred from the voter lists. ${ }^{11}$

Hence, the most important contribution of social scientists to this aspect of the judicial process so far has been to collect data relative to the results (basis number three above) of the selection process attempting to show that important cognizable classes were indeed "substantially"12 underrepresented in the

a Case Study, 10 Am. Crim. L. Rev. 771 (1972); The Jury System: New Methods for Reducing Prejudice (D. Kairys, J. Schulman, \& S. Harring eds. 1975) [hereinafter cited as D. Kairys]. Though it was not applicable in the Little case, the federal statute contains the phrase "selected at random from a fair cross section." 28 U.S.C. $\$ 1861$ (1970). If Congress was using the term "random" in the same way that statisticians and other social scientists use it, this means that a method of selecting persons for the pool must be used that makes every legally qualified member of the community equally likely to be drawn. Hence, not just the outcome but the process of selection is important.

7. D. Kairys $5-24$.

8. W. Flanigan \& N. Zingale, Political Behavior of the american Electorate 9 (3d ed. 1975).

9. People v. Taylor, No. A277-425 (Super. Ct. Cal., filed Oct. 11, 1974).

10. Though social scientists would probably use the term "demographic group," the legal term is "cognizable class." The concept of cognizable classes includes at least all "economic, social, religious, racial, political and geographical groups of the community." Thiel v. Southern Pacific Co., 328 U.S. 217,220 (1946). For a further discussion, see D. Kairys 10.

11. D. Kairys 11 .

12. Here again, legal and social science terminology is different, though each attempts to deal with similar concepts. The courts have used the term "substantial disparity," see id. at 14 , but have 
resulting grand and/or petit jury pool. The method of gathering these data and arriving at a statistical decision is conceptually quite simple. The researcher obtains the race, sex, and other demographic characteristics of the jury pool and compares them with the corresponding characteristics of the general population as revealed in census or sample survey data for the district. However, actually obtaining the data may be quite expensive in terms of time and money and could tax the patience and ingenuity of the social scientists involved.

In order to mount a grand jury compositional challenge for Joan Little, we had to engage in the following steps. First, the jury summons lists since January 1974 were collected from Beaufort County and twenty-two other counties in eastern North Carolina. These lists served as the basis for both the compositional and attitudinal surveys (see below) conducted for the trial. A random sample of 141 individuals was drawn from the jury summons lists of Beaufort County. These people were contacted by phone, at which time attitudinal and demographic information was collected. If the jury summons lists were unbiased, a random sample drawn from these lists should yield a sample that reasonably reflected the demographic characteristics of the general population. However, if the jury pool were biased, a random sample from the jury summons lists would reflect whatever biases were present.

The results of the Beaufort County survey are shown in Table I. It is readily apparent that the jury pool significantly underrepresented blacks. While blacks comprise 30.3 per cent of the Beaufort County residents legally qualified for jury service, only 13.5 per cent showed up in the sample. Thus blacks are underrepresented by an estimated 16.7 per cent in the jury. If the jury pool were truly representative of the proportion of eligible blacks in the county, the chance of our finding this large a difference between the percentage of blacks in the sample and the percentage of blacks in the population is only one out of one thousand.

However, the sample did not indicate that there was any discrimination against women in the Beaufort County jury pool. As can be seen in Table I, the composition of the sample was 53.2 per cent women and 46.8 per cent men. This very closely approximates the composition of the general population of 53 per cent women and 47 per cent men.

While we were able to show a significant underrepresention of blacks in

not spelled out exactly at what point a substantial disparity exists between the proportion of a cognizable class in the jury pool and in the general population. As of now, a substantial disparity exists only when a judge believes it to exist. The social science or statistical term is "significant" and refers to the point where the difference is large enough that such a disparity could have occurred by chance less than five times in one hundred if the sample (in this case the jury pool) had been in fact drawn fairly. See, e.g. W. Hays, Statistics for the Social Sciences 334 (2d ed. 1973); McConahay, Experimental Research, in Handbook of Political Psychology 356, 370 (J. Knutson ed. 1973). 
TABLE I

Proportions of Blacks and Women Legally Qualified for Jury Service in the General population of Beaufort County and in the Jury Pool Sample

\begin{tabular}{|c|c|c|c|c|c|c|c|c|}
\hline & \multicolumn{3}{|c|}{$R A C E$} & \multicolumn{5}{|c|}{$S E X$} \\
\hline & $\begin{array}{c}\text { Per cent } \\
\text { White }\end{array}$ & & $\begin{array}{c}\text { Per cent } \\
\text { Black }\end{array}$ & & $\begin{array}{c}\text { Per cent } \\
\text { Male }\end{array}$ & & $\begin{array}{c}\text { Per cent } \\
\text { Female }\end{array}$ & \\
\hline $\begin{array}{l}\text { General } \\
\text { Population }\end{array}$ & $69.7 \%$ & & $30.3 \%$ & & $47 \%$ & & $53 \%$ & \\
\hline $\begin{array}{l}\text { Jury } \\
\text { Pool }\end{array}$ & $86.5 \%$ & (122) & $13.5 \%$ & (19) & $46.8 \%$ & (66) & $53.2 \%$ & (75) \\
\hline
\end{tabular}

Numbers in parentheses represent actual occurrence in sample.

the Beaufort County jury pool, the court denied our motion to quash the bill of indictment. Our efforts to obtain a change of venue were more successful.

\section{II}

\section{Change of Venue Motion}

When a case has received publicity which would make it extremely difficult to impanel a fair jury or when the issues surrounding the case arouse the racial, political, sexual, or other prejudices of a large segment of the population of the judicial district, a change of venue is one means of increasing the likelihood that the defendant will receive a fair trial. The usual grounds for a change of venue motion are prejudicial publicity or prejudicial attitudes toward the client in the district.

Social scientists who are authorities in communications research and public opinion have been called upon to testify that the evidence presented indicates that prejudice against the defendant is so high that a fair and impartial jury cannot be impaneled in that district.

The evidence presented may vary from copies of newspaper clippings and government press releases to affidavits from people in the community, ${ }^{13}$ but the best evidence from the standpoint of the social scientist is data from carefully conducted public opinion polls. To have scientific validity, these polls must have at least two features: 1) they must be based upon a random sample of persons in the judicial districts, and 2) at least two judicial districts must be polled.

13. D. Kairys 43 . 
A random sample is important because it is the only procedure that insures that the resulting sample will be representative of the population within specifiable limits of confidence, ${ }^{14}$ and it permits the social scientist to conduct valid tests of statistical significance. ${ }^{15}$ Other types of samples (quota, convenience, bellweather, informed observers, and so on) do not meet these criteria and are not valid no matter how loudly they may be proclaimed to be so. Random samples are not haphazard. Whether they are based upon telephone or faceto-face interviews, they are drawn by exact and careful procedures that utilize a chance medium to insure that every member of the relevant population is equally likely to be drawn. For that reason, they are expensive and require a great deal of expertise.

A minimum of two districts must be polled for two reasons. First, social science judgments are relative or comparative. Except at the extremes (i.e., 99 per cent of the potential jurors in this district think the defendant is guilty), comparison with some abstract or absolute standard is either impossible or meaningless as far as the social scientist is concerned. Second, and more important, without at least one comparison district, there is no guarantee that moving the trial will reduce the level of prejudice against the defendant. The new district might have a significantly higher level of prejudice than the original.

One final general point about public opinion polls: The size of the sample has no effect upon its representativeness. Samples of one hundred or one hundred thousand drawn by non-random methods are equally unrepresentative. A random sample of fifty is superior to a non-random sample of five hundred from the standpoint of representativeness. Sample size affects the accuracy of the estimates of opinions and the likelihood of finding a significant difference between two samples, but it is the method by which it is drawn and not its size that determines a sample's representativeness. ${ }^{16}$

It is our opinion that the most important thing we did to insure a fair trial and an acquittal for Joan Little was to present evidence and testimony that secured a change of venue for her trial.

The North Carolina statutes regarding a change of venue permit the trial judge to move a trial from its original county to a contiguous county if, in the opinion of the trial judge, a fair and impartial jury cannot be impaneled in the original county. ${ }^{17}$ If he or she has doubts that a fair jury can be impaneled in a contiguous county, the judge may, at his or her discretion, remove the trial to another county in a contiguous judicial district. ${ }^{18}$ Thus, accord-

14. L. Kish, Survey SAMPling 148-181 (1965).

15. McConahay, supra note 12 , at 373 .

16. L. KisH, supra note 14; McConahay supra note 12 , at 369.

17. N.C. Gen. Stat. § $1-84$ (1969).

18. N.C Gen. Stat. $\$ 15$ A-957 (1969). 
ing to the statutes, it was theoretically possible for the trial judge to remove Joan Little's trial to any one of twenty-three counties within the area generally known as the eastern region of North Carolina. It was the defense's position, however, that the cultural and ethnic homogeneity of the whites in the region created a commonly held value structure that made it impossible for Ms. Little to receive a fair trial in any one of these eastern counties.

In all of these counties agriculture is the primary source of income, the population is spread relatively sparsely across the land, and there has been little in or out migration among whites during this century. Hence, we could expect a great deal of intergenerational continuity in political and value socialization to produce a high degree of conservatism in the white people of the region. ${ }^{19}$ We expected the conservatism of the whites (whom our surveys revealed to be overrepresented in all of the jury pools in the counties of the region) to be reflected in their commonly held, stereotypical attitudes towards race, towards women, towards those in authority, towards women who have been raped, and towards capital punishment. All of these attitudes could strongly influence the final decision of those who would judge Joan Little.

Though we were prepared to argue for a change of venue, county by county for each of the twenty-three eastern counties, Judge Mckinnon ruled that he would allow a change of venue from Beaufort County, the indicting county, to Pitt County. He agreed with us that there would be little chance of securing a fair and impartial jury in Beaufort and he felt that Pitt had more adequate courtroom facilities as well as a larger police force to deal with the expected demonstrators. All other eastern counties were ruled out of consideration.

The defense then tried to convince Judge Mckinnon that a move to Pitt would not improve Ms. Little's chances of getting a fair jury. In order to do that, it would be necessary to move to the more urban Piedmont area of the state. To substantiate our argument, we presented data from the random sample telephone surveys we had conducted in each of the twenty-three counties of the eastern region and in one Piedmont county, Orange. The results from Beaufort, Pitt, and Orange Counties for the exposure, preconception of guilt, and racism questions in our survey are shown in Table 11 .

These data show that there were no differences among the counties in the respondents' perceived level of exposure to the case. Over 75 per cent of those surveyed in these (and the other twenty-two) counties said that they had heard "a lot" about the case. The data also show that though Pitt and Beaufort did not differ significantly from one another in preconceptions of guilt

19. For a discussion of the role of population density and regional migration in political and value socialization and a review of the relevant literature, see D. SEars \& J. McConahay, ThE Politics of Violence 34-54 (1973); R. Ashmore \& J. McConahay, Psychology and America's Urban Dilemmas 107-24 (1975). 
TABLE II

Responses to Survey Items by County for

Beaufort, Pitt, and Orange Counties, North Carolina

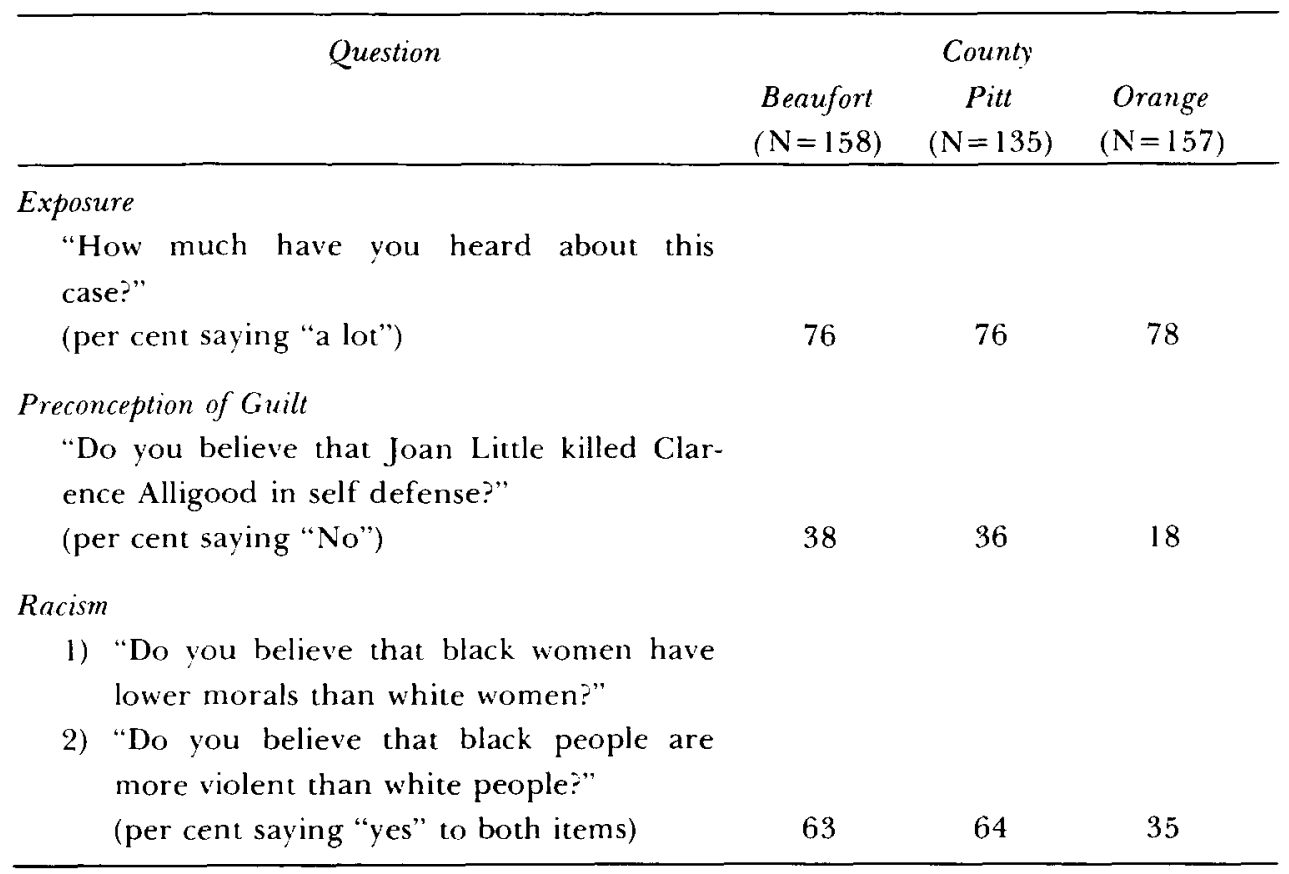

Entries are the percent of a county giving the indicated response. For example 76 per cent of the respondents in Beaufort County said they had heard "a lot" about the case.

and racial attitudes, ${ }^{20}$ they did differ significantly from Orange County. ${ }^{21}$ Hence, we argued that, while a move to Pitt would gain nothing, a move to Orange would make it much more likely that a fair and impartial jury could be impaneled.

We further substantiated our case by introducing evidence developed by academic experts working independently of the defense team. We introduced a survey by the University of North Carolina showing results very similar to ours. Dr. Paul Brandis, also of the University of North Carolina and an authority on the effects of publicity upon attitudes, introduced a content analysis showing that newspaper coverage in the eastern region would induce prejudice. This was buttressed by introducing all newspaper clippings about the Little case from newspapers in the region.

20. All probabilities were greater than twenty in one hundred and hence not statistically significant. See note 12 supra.

21. All probabilities were much less than one in one thousand and hence were statistically significant. Id. 
Expert testimony was also given by Professor Robin Williams of Cornell University who indicated for the court the "resonating effects" which could be expected to occur in a community such as the eastern region of North Carolina. Williams explained that in such areas there exists a societal standard commonly held by the people of the region. Word-of-mouth information dispersal is the primary method by which people become aware of events occurring within their communities. In the case of unusual events that break with the general standards, this procedure serves as a tool to indicate to all inhabitants of the community how people "should" feel about this incident.

Finally, the defense introduced one hundred two affidavits or statements from persons in Pitt County which stated that most people in the county had already formed an opinion about the case.

We convinced Judge McKinnon. Although he did not move the trial to Orange County, where the University of North Carolina has its main campus, he did move it to Wake County, which is also in the Piedmont region and is the location of Raleigh, the state's capitol and one of its largest cities.

When he made the oral announcement of his change of venue decision, Judge McKinnon spoke of the high level of racism which was apparent to him in Pitt County. However, his written order did not mention racism. He based his written decision on the substantial amount of publicity the case had received in the Pitt County news media and the fact that, as a result, many people had fixed opinions about the case. Hence, he feared that an excessively large number of potential jurors would have to be called for examination.

\section{Jury Selection}

The voir dire, or jury selection process, varies across jurisdictions in the United States. In most federal courts, potential jurors are interviewed by the judge, who asks questions submitted to him or her by the prosecution and defense along with his or her own questions. In most state and local courts, the voir dire is conducted with groups of potential jurors. The prosecution, the defense, and the judge ask their own questions of the jurors as a group and of individual jurors in the presence of the other jurors. Less frequently, the individual potential juror is interviewed out of the sight and hearing of the other potential jurors. ${ }^{22}$

In the trial of Joan Little, the judge asked potential jurors, in groups of twelve, general questions--largely regarding their ability to serve for the expected four- to six-week period. Then they were examined individually out of the sight and hearing of other jurors. The prosecution questioned them first

22. For a more complete discussion of voir dire formats, see D. Kairys 25-30. 
and, if they were not excused for cause, made a decision to accept or peremptorily challenge the juror. Once it had passed a juror, the prosectuion could not change its decision. At this point, the potential juror was examined by the defense and, if the person was not excused for cause, the defense had to decide to accept or use one of its peremptory challenges. If the defense accepted a juror, he or she was immediately sequestered in the jury room. This process continued until sixteen jurors (twelve regular jurors and four alternates) were seated. The process of jury selection took ten working days during which over two hundred potential jurors were interviewed.

Six streams of data were combined in the defense's decision to accept or reject a potential juror. First, on the basis of a random sample survey of Wake County, ${ }^{23}$ we had developed a mathematical model of the juror who would be ideal for the defense. Second, we observed the behavior of the potential juror during the voir dire and rated him or her on a psychological characteristic known as authoritarianism. ${ }^{24}$ Third, we observed the "body language" including both kinesic and paralinguistic behavior in order to determine the degree to which a potential juror was defense or prosecution oriented. ${ }^{25}$ Fourth, the attorneys ${ }^{26}$ drew upon their voir dire experience and common sense. Fifth, we had a psychic ${ }^{27}$ who observed the potential jurors and advised us of their aura, "karma," and psychic vibrations. Finally, Ms. Little was asked how she felt about any juror whom we were seriously considering accepting.

We shall go into more detail on the first three of these in the next few sections of this article. It is beyond the scope of our task here to make any comments upon the judgments of the attorneys, the psychic, or Ms. Little except to note three observations. First, all streams of data pointed to the same decision in about 90 per cent of the cases. Second, when there was disagreement, a majority of the lawyers and Ms. Little usually went with the decision indicated by the scientific evidence. Finally, given the political nature of the trial, the publicity value of a psychic should not be underestimated. He helped to keep the eyes of the world upon the defense, the prosecution, the judge, and Raleigh, North Carolina.

\section{A. The Survey and Mathematical Model}

Although it was expensive to construct (about $\$ 35$ thousand), the most important scientific tool we had was the mathematical model of the defense's

23. Jeffrey Frederick was in charge of the calculations based upon the mathematical model. He was ably assisted in the courtroom by Diane Ford Krowe and Barbara Heokje.

24. Courtroom observations of authoritarianism were conducted by Richard Christic, John McConahay, and Georgina Hancock.

25. David Suggs and Courtney J. Mullin conducted most of the body language observations.

26. Chief defense counsels were Jerry Paul and Karen Galloway. They were assisted by Morris Dees, Marvin Miller, James Rowan, and Milton Williamson.

27. The psychic was Richard. 
ideal juror based upon a random sample survey of Wake County. Its effectiveness rested upon two assumptions which, fortunately, proved to be justified. First, we assumed that the jury pool would be close to a random sample of the citizens of Wake County eligible for jury service. Second, we assumed that those characteristics of the survey respondents which enabled us to predict opinions regarding Joan Little's guilt or innocence in the sample survey would also enable us to predict them in the jury pool.

In order to facilitate a general understanding of the mathematical model by readers unfamiliar with statistical methods, it will be described in a brief, nontechnical fashion. The basic idea behind this approach is that individuals who are predisposed to believe that the defendant in question is guilty will differ from other individuals with respect to a number of observable characteristics. Once these characteristics have been identified for the population as a whole, they can be used to predict the predispositions of each potential juror.

Before the model can be employed, a survey of attitudes in the particular geographical area of interest must be undertaken. This provides an assessment of the attitudinal composition of that area from which the mathematical model will then generate its predictions. The mathematical model itself is a predictive hybrid of several statistical techniques. First, we chose an appropriate measure of the attitudes or opinions we wished to predict, i.e., belief in the guilt or innocence of the accused. Next, a series of statistical techniques was employed to determine what demographic characteristics of the respondents in the sample would act as predictors of these important opinions. Demographic characteristics might include age, race, sex, political and religious affiliations.

In the first phase of the procedure, an attempt was made to divide the sample into groups possessing similar opinions. That is, if those of higher ages and lower ages differed in their opinions regarding the guilt or innocence of the accused, it would be helpful to divide the sample into younger and older age groups before an attempt was made to formulate predictions of their important opinions. This was accomplished by using a modified version of a statistical computer program known as AID (Automatic Interaction Detection).

The AID program searched the survey data until it had successfully divided the sample into as many groups as possible based upon the homogeneity of the sample members' opinions. Membership in any one homogeneous group was often defined by several demographic characteristics-for example, young democrats with at least a college education. As a result of this first phase, our ability to predict opinions was increased by decreasing the variability of our sample.

After the sample was divided into groups of individuals with fairly similar 
opinions, each group was examined to establish which of their social and psychological characteristics were important with respect to our abillity to predict a potential juror's opinions. In more technical terms, this phase was concerned with the formulation of predictive equations for jurors' opinions. In order to do this, we used a technique known as multiple regression, which enabled us to develop a mathematical model of the opinions of potential jurors based upon a series of characteristics that differed from one demographic group to another. An example of this would be the case where one group produced by phase I consisted of young democrats with at least a college education. For members of this group we may need to know the sex, religious attitudes, and income characteristics of the individuals. In another group from phase I. e.g., democrats over forty-five years old with a high school education, the terms in the predictive equation might be the type of magazines read, sex, and preferred presidential candidate.

Though the social and psychological factors used to predict opinions varied from group to group, they combined to form the same thing: a prediction of the likelihood that a potential juror would be willing to vote Joan Little not guilty before hearing any of the evidence.

One of the advantages of this procedure is obvious. Regardless of what a juror might say during the voir dire, by observing or obtaining his or her demographic characteristics (age, education, etc.) and social-psychological characteristics (politics, reading habits, etc.), the mathematical model enabled us to predict how predisposed he or she was to side with the prosecution or defense. Potential jurors might lie about their preconceptions of guilt or innocence, but they were much less likely to lie about their age or education.

A second advantage is not so obvious. Because the judge permitted both prosecution and defense to send out with the jury summons a questionnaire concerning the jurors' demographic characteristics, ${ }^{28}$ we were able to get a preliminary estimate of what proportion of the jury pool would be predisposed to be "pro-defense" or "pro-defendant" before the voir dire began and before we had seen a single juror. The advantage here is that in the early part of the voir dire we could afford to let some promising jurors go because we knew that better potential jurors would appear later. Many of the news reporters failed to see how important this was. Informally, if not in print or on the air, they expressed the opinion that the mathematical model and the other scientific procedures were not necessary because anyone would have known we wanted health food waitresses (the final jury had two of them) and a former drama major turned record store manager. What they failed to

28. The questionnaire sent to jurors with their summons did not, of course, have any questions about the impending trial, about their attitudes toward Ms. Little, nor about their preconceptions of her guilt or innocence. 
notice was that we got these persons as jurors because we had not already filled the slots with secretaries and IBM engineers.

\section{B. Authoritarianism}

Although we expected the math model to be between 85 per cent and 95 per cent accurate, we supplemented it with courtroom observations of authoritarianism and body language. Our observations of authoritarianism were based upon the theory of the authoritarian personality developed in the $1950 \mathrm{~s}$ by researchers at the University of California at Berkeley. ${ }^{29}$

According to this theory, which is supported by mountains of empirical research, ${ }^{30}$ extreme authoritarians are rigid, racist, anti-semitic, sexually repressed, politically conservative, highly punitive individuals who will accept the word of an authority figure over that of a lesser person. The authoritarian is servile and obsequious in a subordinate position, but takes out all of his or her pent-up hostility and frustration upon those perceived to be in violation of the conventional norms of society. ${ }^{31}$

It is obvious that no defense attorney would want a jury loaded with extreme authoritarians. However, people vary in the degree to which they exhibit authoritarian personality traits. To the extent that potential jurors are more or less authoritarian, we would expect them to be more or less desirable from the viewpoint of the defense as jurors in trials involving minority persons, political and social nonconformists, or other controversial defendants. It is possible that the juror's level of authoritarianism might be something of a factor in all criminal trials. In the adversary system, the juror must weigh the evidence and arguments presented by the prosecution on behalf of the state or society and by the defense attorney on behalf of someone accused of a crime and therefore of lower status then the prosecutor.

The procedure for observing prospective jurors and rating their level of authoritarianism was developed by Richard Christie for use in the Harrisburg Eight trial. Christie had refined the procedure in a number of subsequent criminal trials, and in fact he was present at the Little trial to observe the potential jurors and to train others in the use of his observation and rating technique.

29. 1. Adorno, E. Frenkel-Brunswik, D. Levinson, \& R. Sanford, The Authoritarian Personality (1950).

30. The most complete critical summary of the theory and empirical research testing the theory of the authoritarian personality may be found in R. Brown, Social Psychology 477-546 (1965).

31. The hypothesized psychodynamic origins of the authoritarian personality syndrome are highly controversial in academic psychology. R. BRown, supra note 30. However, we did not need to dig into the psychological history of prospective jurors in order to rate their authoritarianism. If they exhibited authoritarian behavior during the voir dire, we rated them as authoritarian regardless of how they got that way. 
The authoritarianism rating scale we used in the courtroom ranged from a low of zero which represented minimum authoritarianism to a high of thirty which represented maximum authoritarianism. The neutral point between high authoritarian and low authoritarian behavior was fifteen. Christie's experience in a number of trials suggested that the average American rated about twenty on this scale of authoritarianism. By observing the authoritarianism-related behavior of potential jurors-their rigidity, their sexual prudery, their introspectiveness, and so on-three social psychologists were able to rate reliably the person's level of authoritarianism. When a decision was made to accept or reject a potential juror, these independently made, written ratings were combined to feed an authoritarianism rating into the decision making process. ${ }^{32}$

The average rating assigned by our observers to all persons who were interviewed for Ms. Little's jury was 21.02, which is not very different from the general American population. On the other hand, the average for the sixteen seated jurors was 14.03. For the twelve who made the final decision to acquit her, the average authoritarianism rating was 12.95. Thus, we were able to pick a jury which was significantly less authoritarian than the jury pool as a whole.

\section{Body Language}

In a highly publicized case such as Ms. Little's, there were some people who actively desired to be on the jury. These people might have said whatever was necessary to insure that they were picked for the jury. Some of them could be expected to be pro-defense, some to be pro-prosecution. It was crucial for the defense to determine in some way the truthfulness of the jurors being selected. To do this, we called upon the newly emerging science of kinesics and paralinguistics, i.e. body language.

Although people frequently communicate their true feelings in the words they speak, it is now clear that we can also communicate a great deal of information by means of our body movements, gestures, positions, vocal intonations, pauses and the like. In other words, it is not what we say but the way we say it. We are perfectly capable of expressing one type of attitude with our language and a diametrically opposed attitude with our body language, for example, by unduly long pauses when speaking or by loudness or softness of the voice.

Our approach was to measure the levels of anxiety expressed by the indi-

32. The average interrater reliability of our ratings was .84 , and our courtroom authoritarianis $m$ ratings correlated .82 with a verbal scale of authoritarianism administered by our interviewer both to the jurors who served in the trial and to a sample of potential jurors whom we rejected. Hence, we had highly satisfactory levels of reliability and validity by these measures. For an elementary discussion of measures of reliability and validity, see McConahay, supra note 12, at 364 . 
viduals being questioned. We employed five variables to determine the kinesic response (body movement, body orientation, body posture, eye contact, and hand movement). We also employed two paralinguistic measures (vocal intonation and vocal hesitancy).

No single kinesic or paralinguistic response determined the acceptance or rejection of any juror. We were looking for patterns of behavior. Human communication is extremely complex and one must look at the whole in order to make any determination as to the attitudes being expressed. Some popular writers on the subject would have one believe that a single gesture is indicative of an overall attitude. ${ }^{33}$ In truth, the single gesture must be deeply incorporated into a pattern of response expressed throughout the body and by the voice. $^{34}$

David Suggs, of the University of Nebraska, was our expert on body language. He and one and sometimes two other observers trained by him noted each prospective juror's pattern of kinesic and paralinguistic behavior (described above) and rated the juror on a scale ranging from one point, least favorable to the defense, to five points, most favorable to the defense. These preliminary ratings were written down independently by each observer and then combined to form a final five point rating of the juror's attitude toward the defense (a high score indicating maximum favorableness).

To assess the relationship between the measures made on the basis of authoritarianism and body language, we correlated the two scales. The overall correlation was -.79 . This correlation was high and indicated that authoritarianism was associated with being least favorable toward the defense. The correlation was not so high, however, as to indicate that the two scales were simply measuring the same phenomena. Each measure both reinforced and added to the other. The use of both approaches insured more complete knowledge of the attitudes of the potential jurors than the use of either alone.

\section{The Final Decision}

When, in the course of the voir dire, a member of the defense team thought that a decision should be made on the potential juror under consideration, a conference was called. At this point, the members of the team put their heads together in a fashion that resembled a football huddle. Each social scientist read to the team from a written estimate of the potential juror based upon the juror's demographic rating, authoritarianism, or body language. In this way we minimized the influence upon an estimate from one technique (e.g., body language) by another technique (e.g., authoritarianism). The attorneys, the psychic, and Ms. Little also indicated their opinions of the potential

33. Katz, The Twelye-man Jury, 5 Trial no. 1, at $39-42$ (1968-69). See also J. Fast, Body LANGUAGE (1973).

34. A. E. Scheflen \& A. Scheflen, Body Language and Social Order (1972). 
juror in this "huddle." One of three decisions was made: accept, reject, or obtain more information.

If the decision was to accept, we either indicated acceptance at that time or asked a few more "soft" questions in order to educate the juror and establish further rapport. If the decision was to reject, we began a line of questioning which attempted to get the potential juror excused for cause. ${ }^{35}$ The defense team was very successful at getting people whom we did not want excused by the judge for cause. By the time we were choosing the twelfth juror, we had thirteen of our original fourteen peremptory challenges left while the prosecution had expended eight of its original nine peremptories.

When there were disagreements among the members of the team about a given juror, we continued to obtain information by asking more informational questions until we could reach agreement to accept or reject. As indicated above, when we had sufficient information, the scientific evidence pointed toward the same decision in over 90 per cent of the cases. Furthermore, as our advantage over the prosecution in peremptory challenges increased, we became more and more cautious about whom we accepted so that if only one of the streams of scientific data suggested a rejection, we rejected. This meant that we were virtually unanimous about the sixteen jurors finally accepted.

At the close of the five week trial, the jury took seventy-eight minutes to find Ms. Little not guilty of all charges.

\section{IV \\ Ethical and Policy Issues}

Reactions to the incursion of social scientists into the judicial system have been mixed but not quiet. A distinguished professor of law heartily congratulated us for doing "what every trial lawyer tries to do: stack the jury." An equally distinguished professor of psychology berated one of the authors for over half an hour for subverting justice by "stacking the jury." Another social scientist, Amitai Etzioni, has compared the application of social science to jury selection with Adam's legendary nibble from the apple that got our forebearers banished from paradise. ${ }^{36}$ Other commentators, pro and con, have been

35. The most obvious way to get prospective jurors excused for cause was to get them to say in court that their minds were so made up beforehand that they could not set their prior opinions aside and decide the case only on the basis of the evidence they encountered during the trial. However, we were also able to excuse for cause a number of other prospective jurors who said they would let the fact that Ms. Little did not take the stand influence their decision and/or who said that they would hold it against her if she did not put forward any evidence in her defense. Both of these rights are guaranteed to defendants by the United States Constitution. The prosecution also had a favorite method of getting prospective jurors excused for cause; opposition to the death penalty. In fact, thirty-seven of the first thirty-eight blacks who were interviewed as prospective jurors said that they were opposed in principle to the death penalty. Not all of them. however, were so opposed that they had to be excused for cause.

36. Etzioni, Creating an Imbalance, 10 TRIAL no. 6, at 28 (1974). 
equally excited and agitated about what has happened. ${ }^{37}$

It is scientific jury selection that has aroused the controversy. Our efforts to challenge the jury pool composition and to seek a change of venue went generally unnoticed. We hypothesize that this occurred in part because the procedures do not appear very "sexy" to those knowledgeable in statistics, and in part because they are viewed by social scientists as making the system more just. If the law says juries must represent a cross-section of the population, then making jury pools more representative helps to reform the judicial system. Changing the venue is probably viewed similarly, with the added bonus that it can save tax dollars by avoiding a situation where a trial must be moved because an impartial jury cannot be impaneled after days or weeks of voir dire. Therefore, since it is scientific jury selection that arouses the controversy, we shall limit our discussion to this aspect. ${ }^{38}$

Now that we have been involved in the Little trial and a number of others, it is our opinion that two issues must be faced before we address ethical or policy questions. First is the context in which social science is being applied: the American adversary system of justice in theory and as it really exists. Second is the question of the efficacy of scientific jury selection. Does it really make a difference in the outcome of trials?

\section{A. The Adversary System}

The intensity of condemnation of scientifc jury selection is, generally, inversely proportional to the critic's knowledge of and experience with the American adversary system of justice. Therefore, at the risk of offending our readers who are familiar with the system, we shall give a brief, elementary summary of the philosophy that guides our system.

The American legal system, at least, is based upon an adversary model of procedural justice. ${ }^{39}$ It is assumed, at least in theory, that justice will emerge

37. Very personal communications to the three authors.

38. In a few instances a criticism of any involvement of social scientists as advocates in an adversary process has been voiced. The basis of the criticism is that such involvement threatens the "objectivity" of social science and social scientists, and hence reduces our credibility in the world at large. Though it is most often voiced by graduate students, this notion of objectivity as neutrality sounds quaint given the current understanding of these terms by most active social science researchers. For elementary discussions of these points from the standpoint of modern social science researchers, see D. Sears \& J. MCConahay, supra note 19, at viii-ix; R. Ashmore \& J. McConahay, supra note 19, at 1-11; 144-156. Such criticisms also ignore the fact that objectivity or neutrality in this sense is simply to give support to the status quo or to the forces with the most power. At any rate, the issue is one that is more appropriate for discussion within the social science guild rather than in an interdisciplinary journal.

39. Procedural justice refers to the procedures for settling disputes or determining guilt or innocence. This form of justice should be distinguished from "distributive" justice which refers to the just allocation of outcomes and resources. For an elementary discussion of the distinction between distributive and procedural justice, see $\mathrm{J}$. Thibaut \& L. Walker, Procedural Justice: A Psychological Analysis 3 (1975). For a social psychological analysis of distributive justice, see Adams, Inequity in Social Exchange, in 2 Advances in Experimental Social Psychology 267 (L. 
from contending sides (prosecution and defense, plaintiff and defendant) possessing equal resources, doing their best to present the strongest possible case, or to look after the interests of clients in the strongest possible way. ${ }^{40}$ In the adversary system, the decision maker is a third party, the judge and/or jury. This third party is supposed to remain neutral and render the decision after hearing both cases made by the contending advocates. In criminal cases, there is one additional rule that the decision maker is supposed to follow. The defendant is presumed innocent until guilt is established beyond a reasonable doubt.

Other legal systems depart from this basic procedural theory in critical ways. ${ }^{+1}$ The prosecutor and decision maker may be the same person, or the fact finder may combine both the prosecutorial and defense attorney roles, or the defendant may be required to prove his or her innocence rather than being presumed innocent with the burden of proof falling upon the prosecution. But in the American system, the three roles (prosecution, defense, and decision maker) are kept distinct. As a consequence, if someone wishes to introduce certain skills or knowledge in to the adversary system and that person does not happen to be a judge or juror, the usual way is to enter on behalf of one of the adversaries.

Empirical research by John W. Thibaut and Laurens Walker ${ }^{42}$ demonstrated that when the assumptions of the various procedural justice systems are met, the adversary system has the following advantages over other systems, particularly the inquisitorial system used in most European countries. First, more facts emerge, presumably leading to a "truer" picture of what actually happened. Second, the "right" outcome, an outcome most congruent with the facts and with notions of distributive justice, is more likely to occur. Third, both the parties winning and losing the dispute are more likely to feel that the procedure is fair. That is, the adversary system has greater perceived justice. Finally, potential litigants, even the Europeans, prefer the adversary system before they know which side they will be on and how strong their case will be. Hence, it appears that, in theory at least, the adversary system is superior to other systems of procedural justice. ${ }^{43}$

However, the American adversary legal system as it actually exists departs

Berkowitz ed. 1965). For a philosophical discussion of distributive and procedural justice, see J. RAWLS, A THEORY OF JUSTICE (1971).

40. There are, of course, restrictions on what the advocates can do in pursuing their clients' interests. They cannot, for example. suborn perjury or tamper with evidence. Sep J. ThIBaut \& L. WALkER, supra note 39 , at 29.

41. Id. at $22-27$.

42. Id. That is what the whole book is about.

43. Not everyone would agree that Thibaut and Walker clearly demonstrated the superiority of the adversary system, especially in criminal trials. See Vidmar, Choosing, Finding, and Evaluating Methods of Obtaining Legal Justice, 21 ConTemp. Psych. 773 (1976). 
in a number of important ways from the theoretical model. ${ }^{44}$ One key assumption of the model is equal resources for the adversaries. Observers, though, generally agree that in practice that is not the case. While Etzioni feels that scientific jury selection has tipped the balance of resources in favor of the defendants, or at least those defendants who have political or financial resources, ${ }^{45}$ Howard A. Moore, Jr., an attorney who has defended Angela Davis and other radicals, asserts that when minority group members or political nonconformists are on trial the general population's high level of prejudice gives the prosecution a built-in advantage. ${ }^{46}$ Other critics of the existing system perceive that in most criminal trials the state has much greater resources to investigate both the case and potential jurors. ${ }^{47}$

A second critical assumption of the adversary model is that the juror, or other decision maker, understands the concept of presumption of innocence and is willing to apply it, can set aside his or her emotions and prior knowledge, and can render a decision based solely on the admissible evidence while properly applying the reasonable doubt standard. These traits and skills are even rare among scholars and scientists who have been trained to acquire them at great expense and over years of time. Consequently, in the current American system we have to use mortals who fall short of the ideal.

These weaknesses of the average juror and the pressures of the adversary system lead contending teams of lawyers to seek jurors who favor their client. If they cannot find such people, then lawyers will usually settle for persons who are reasonably fair-minded.

Since the first lawyer defended the first client before a jury in an adversary process, lawyers have used intuition, rules of thumb, and folk psychology and sociology to guide them in choosing jurors. Clarence Darrow's prescription for selecting juries favorable to the underdog clients whom he frequently represented was to reject prohibitionists, Presbyterians, Baptists, Scandinavians, and the well-to-do, while accepting Jews, agnostics, Irishmen and especially looking for those who liked to laugh. ${ }^{48}$

In the Little trial, the adversary system worked fairly well with respect to the jury's level of authoritarianism. We rejected the extremely high ones and

44. For a review of empirical studies and critiques of the actual criminal justice system in America, see R. Ashmore \& J. McConahay, supra note 19, at 87-106.

45. Etzioni, supra note 36 .

46. Moore, Redressing the Balance, 10 Trial no. 6, at 29, 31, 35 (1974).

47. J. Casper, American Criminal Justice: The Defendant's Perspective 77 (1972). See also R. Ashmore \& J. McConahay, suprn note 19, at 96-101. It has been alleged that the federal government used the resources of the FBI and other agencies to investigate and interview prospective jurors in their homes. See D. Kairys, supra note 6 . This is potentially much more effective for selecting the right jurors than mathematical models of courtroom observations.

48. Kahn, Picking Peers: Social Scientists Role in Selection of Juries Sparks Legal Debate, Wall St. J. Aug. 12, 1974, at 1, col. 1. 
the prosecution eliminated the extremely low. As a result, while individual members of the jury varied in their authoritarianism, the jury as a whole was very close to the neutral point. ${ }^{49}$ Hence, the overall jury was not particularly biased either way.

An even less authoritarian jury might have been better from the standpoint of the theoretically ideal juror. According to experimental research by Mitchell and Byrne, such legally irrelevant factors as the defendant's attractiveness and similarity to the juror bias the decisions of high authoritarians, but low authoritarians are more likely to decide on the basis of the facts presented. ${ }^{50}$

\section{B. Does it Work?}

Etzioni believes that scientific jury selection is effective and that it should be banned because it gives one side an unfair advantage. ${ }^{51}$ In an article in Psychology Today, Michael Saks has asserted that scientific jury selection does not work and that we should forget about the whole thing. ${ }^{52}$ Saks's argument was rather weak because the studies he cited were mostly his own unpublished work and he did not describe his methodology in sufficient detail to enable us to evaluate the validity of his findings. Nevertheless, the question he raised is crucial. If scientific jury selection does not have an appreciable effect upon a trial's outcome, then the controversy over its use should revolve around issues of fraud and not jury stacking.

We believe that our efforts made a difference in the outcome of the Little trial, but because there was no control group, ${ }^{53}$ we can never be certain in the scientific sense. Judge Hamilton Hobgood called the case presented against Ms. Little one of the weakest he had seen in more than twenty years on the bench. ${ }^{54}$ It is possible that any jury would have found her not guilty. Furthermore, even if scientific jury selection did produce an acquittal, it might have been for the wrong reasons. We can think of three other hypotheses to account for the results in addition to the notion that we chose jurors with appropriate psychological and social backgrounds.

49. See text at p. 220 supra.

50. Mitchell \& Byrne, The Defendant's Dilemma: Effects of Jurors' Attitudes and Authoritarianism on Judicial Decisons, 25 J. Personality \& Soc. Psych. 123 (1973).

51. Etzioni, supra note 36 .

52. Saks, Social Scientists Can't Rig Juries, 9 Psych. Today no. 8, at 48 (1976).

53. In experimental design, a control group is one that is like the experimental group in every way except that it did not receive the experimental treatment. In this case, the experimental group would be a set of trials in which scientific jury selection was used and the control group would be a set of trials equal in every way (through randomization) to the trials in the experimental group. Any difference between the outcome of the trials with scientific jury selection and those without could be attributed only to the use of scientific jury selection rather than to other factors such as differences in evidence, jurisdiction, judges, and so on. See McConahay, supra note 12, for an elementary discussion of experimental designs for nonlaboratory research.

54. Wake Jury Acquits Joan Little, Says State Didn't Prove Its Case, Raleigh News \& Observer, Aug. 16, 1975, at 1, col. 5. Statement of Judge Hobgood appears at 5B, col. 6. 
The first of these is what might be called a talisman, or placebo, effect. The effect might not be on the jurors but on the lawyers. Any trial, but especially a big one, has elements of a major psychological struggle between the two adversary teams. If one side thinks it has a new weapon, its spirits are boosted. This increase in morale could result in a more diligent search for evidence, a more vigorous cross-examination of witnesses, or a more confident and forceful closing argument than would otherwise have occurred. The sight of all those experts advising their opponents could have a dispiriting effect upon the other side as well.

The second possibility is that the effect might be upon individual jury members for reasons that have little to do with their psychological and demographic backgrounds. The prosecution in the Little trial, and in all of the trials in which we have participated, took pains to let prospective jurors know that we were there to "psychoanalyze" them or to use a "Ouija board" to find the right jurors. The prosecution was obviously hoping to create a state of psychological reactance $^{55}$ that would produce a boomerang or backlash against us. In fact, this tactic might have produced an effect reinforcing our efforts. Regardless of their backgrounds, the knowledge that they were chosen by "experts" for their ability to give the defendant a fair trial might have produced a special bond between the jurors and the defense, hence producing the outcome sought by the defense in the same manner that "demand characteristics" 56 and "Hawthorne effects"57 predetermine the outcome of psychological experiments when the participants in the experiment know that they are being observed.

A third possible alternative hypothesis is that the jury's group cohesiveness was increased. In the many, many laboratory experiments on group dynamics, the principal method of creating a high level of cohesiveness is to inform the members of a group that they have been especially chosen because they have some desired attribute or characteristic in common with one another. ${ }^{58}$ In this instance the common attribute might be fairmindedness or political or racial

55. Psychological reactance is the tendency to attempt to assert one's independence and "free will" by acting (or reacting) in a fashion opposite to that desired by the manipulator whenever a person feels manipulated by someone or some situation. J. BreHM, Responses to Loss of FreEdom: A Theory of Psychological Reactance (1972).

56. Demand characteristics are those aspects of situations, especially "scientific " research situations, which pressure or "demand" a person either to do something in order not to be thought odd, or to act contrary to the way that "science" predicts that he or she should behave. McConahay, supra note 12 , at 381 .

57. Hawthorne effects are a special form of behavior in conformity to the demand characteristics of a situation. See note 56 supra. For a discussion of Hawthorne effects, see Kraut \& McConahay, How Being Intervieuted Affects Voting: An Experiment, 37 Pub. Opinion Q. 398, 406 (1973). See also McConahay, supra note 12, at 367.

58. Collins \& Raven, Group Structure: Attraction, Coalitions, Communication, and Power, in 4 THE Handbook of Social Psychology 102, 199 (2d ed. G. Lindzey \& E. Aronson 1969). See also 1. JANis, Victims of Groupthink (1972). 
attitudes. The group dynamics research literature suggests that if cohesiveness is increased in this fashion, the increased use of scientific jury selection by one side or the other will have two main effects. First, there will be a decrease in hung juries due to the increase in conformity pressures within the jury. ${ }^{59}$ Second, there will be a greater likelihood that the direction of the final verdict would reflect whatever trends there were in the first few rounds of jury deliberation. Hence, this technique should be used sparingly in situations where the lawyers are hoping for one or two people to hang the jury or convince the majority to go with their side.

There are also a number of sound reasons to expect that scientific jury selection does work and that it does so because of the composition of the resulting jury. Our own, unscientific poll of the trial lawyers we know resulted in the following estimate: that 85 per cent of all criminal trials are decided on the basis of the evidence while 15 per cent are influenced to some extent by the jurors' biases. In political and other controversial trials, however, this ratio may be closer to fifty-fifty. More important is the long tradition of research into the effects of attitudes upon perceptions and decisions. ${ }^{60}$ It is a wellestablished finding of this research that, although attitudes are not the only determinant of the person's decision, they are a major influence that increases in power as the emotions and attitudes of the decision maker become more extreme and the evidence becomes more ambiguous. However, the most important reason for suspecting that scientific jury selection is effective is the string of acquittals and hung juries in which it has been used. The odds are less than four in 100,000 that such a string of outcomes could have occurred by chance. ${ }^{61}$

The issue of the effectiveness of scientific jury selection can only be settled by empirical research. This research will not be easy to carry out. For example, while we interviewed both the jurors and a random sample of the persons we rejected as jurors for Joan Little, the jurors were much more likely than the non-jurors to be convinced that the defendant was not guilty; moreover, the non-jurors did not hear the evidence nor did they have the pressures on them to stick by a not guilty verdict. The problems involved in performing field research on actual trials are the same problems that are faced by anyone

59. Id.

60. The studies showing this effect are legion. See, e.g., S. Asch, Social Psychology (1952); R. Ashmore \& J. McConahay, supro note 19, at 1-11; M. Sherif, The Psychology of Social Norms (1936); Ashmore, Prejudice: Causes and Cures, in B. Collins, Social Psychology 243-339 (1970); Hastorf \& Cantril, They Saw a Game: A Case Study. 49 J. A bnormal \& Social Psych. 129 (1954); Mitchell \& Byrne, supra note 50.

61. Based upon the assumption that in each of the fifteen trials where we know these techniques were used. it was equally likely that the defendants could have been acquitted or convicted, $i . e,(.50) .^{15}$ : If the probability of conviction was greater than fifty-fifty, say .75 , then the likelihood of this string of acquittals occurring by chance is even lower. 
attempting to evaluate a selection or screening technique, whether it is for admission to a graduate school or a mental hospital. Since the researchers cannot ethically admit candidates at random to the program, hospital, or jury, the persons chosen are already extreme on the dimension or dimensions of interest introducing the problem of regression effects. ${ }^{62}$ Furthermore, the chosen people differ crucially from those screened out in their subsequent experiences. Rigorous field work could be done in this area, but it would be very time consuming and expensive. ${ }^{63}$

It would probably be best, therefore, to start with a series of laboratory experiments using simulated juries and carefully constructed, fictitious cases. If the results of these studies in a controlled situation prove suggestive, then we could move on to more elaborate and expensive field research.

\section{Conclusion}

We have discussed three uses of social science in the criminal process: 1) to challenge grand jury composition; 2) to provide evidence for a change of venue; and 3) to choose jurors. Of these three, only scientific jury selection has aroused any opposition in popular and semi-scholarly literature. We think that most of the opposition is based upon a naive understanding of both the theory and actual practice of the American adversary system of criminal justice, and that it is too early to make any definitive policy recommendations until more research has been done to examine if and why scientific jury selection affects the outcome of jury decisions.

This is not to imply, however, that we are sanguine about the use of scientific jury selection. We are concerned about the potential psychological dam-

62. There is some error in any measurement or selection technique. Persons who are extreme (either very high or very low) the first time these techniques are applied (as during the voir dire) were made extreme. in part because the errors "pushed" them away from the mean. In a second measurement, as when evaluating the technique. the errors in the first measurement will be replaced by a second set of errors which, on the average, will make the persons who were extreme the first time less extreme the second. Hence, they will have "fallen back" or regressed toward the mean. This makes it almost impossible to evaluate rigorously a selection technique without at random control group, see note 53 supra, or numerous cases or both. Since there is no control group and only a small number of cases, a rigorous evaluation of any one instance of scientific jury selection is impossible. For detailed discussions of regression effects, see $\mathrm{D}$. CaMpbell \& J Stanley, Experimental and Quasi-Experimental Designs for Research 10 (1966): M(cConahay, supra note 12 , at 365 .

63. An "ethical" experimental study would require at least three groups of fifteen jury trials each. The trials would be assigned randomly to groups. McConahay, supra note 12 , at 369 . In the first group, the experts would select the best jury possible using their techniques. In the second group of trials, the jury experts would simply reinforce the selections that the clients' lawyers would have made anyway. In the third group, the outcome of the trials with no jury selection experts involved would be noted and recorded. This last group would thus serve as the baseline control for the outcome of trials in that jurisdiction. This experiment, while methodologically elegant and rigorous, would be very expensive since it would have to be financed by persons other than the clients. Further, it might still be considered unethical by some observers. 
age to those persons called for jury service and then rejected as jurors by a team of social scientists which includes psychologists. We cannot be certain how great this potential is, but we do have evidence which suggests that being called for jury duty, interviewed extensively, and rejected was not a pleasant experience for Ms. Little's potential jurors. For example, though virtually all of the sixteen jurors who heard the case were willing and eager to talk with our follow-up interviewers, most of the rejected jurors refused to be interviewed. Those who did consent expressed negative feelings toward the experience and a desire to forget the whole thing. Without a control group we cannot ascertain whether all potential jurors who are rejected react the same way. Further research into this question is needed.

We also are concerned, with Etzioni and others, that the use of these expensive techniques will magnify the already huge disparity between the quality of defense available to the rich and well-connected, and that available to the poor and marginal.

Moreover, routine use of these techniques by both prosecution and defense may simply cause each side to cancel the other out while raising the cost of a jury trial to both. Thus, we may raise the status quo ante in a system of justice that is already very expensive to both sides.

Finally, though we would rather see some guilty defendants acquitted than have innocent defendants convicted, we are concerned that the techniques could result in the acquittal of persons who were guilty. The fact that the present authors have maintained their own moral purity by never working for persons who seemed to us clearly guilty of the crime with which they were charged does not lessen our concern in this regard.

Because of these concerns, we think that more research is necessary before we can recommend any policies intended to change the existing system. The policy recommendations that have been made, especially Etzioni's, ${ }^{64}$ are

64. Etzioni, supra note 36 , has made four policy recommendations intended to curb the use of scientific jury selection. First he suggests decreasing the number of grounds for excuse from jury duty and increasing the number of persons called for jury duty in order to make a more representative universe from which jurors are selected. We would applaud this, but do not see how it will curb the use of scientific jury selection. Second, he recommends reducing the number of challenges, especially "preemptory" challenges. We would oppose this if he wants to reduce the right to challenge for the constitutionally guaranteed causes such as a presumption of innocence. Furthermore, reducing the number of peremptory challenges may make it even more important to use scientific selection of jurors. Etzioni's third recommendation is to extend the ban on jury tampering to all out-of-courtroom investigations of jurors. This is fine with us if it applies to the FBI and local police as well, but it still would have had no effect on what we did for Joan Little because we did not investigate the jurors outside the courtroom. We observed them inside the courtroom and compared them to data gathered on the population as a whole.

Etzionis final recommendation reveals that he has not had much experience in actual courtrooms or jury trials. He suggests that only judges be allowed to question and remove prospective jurors. What is interesting here is that he is recommending what is already done in the federal courts, and it was in the federal courts that scientific jury selection originated and achieved some of its most startling successes. 
either beside the point in the existing adversary system or premature. Only further research can pinpoint what, if any, effects have resulted from this intrusion of social scientists and social science into the judicial process. We predict that there will be ample opportunity for such research as these techniques are used increasingly over the next few years. 